\title{
Growth and Carbon Metabolism of Tall Fescue and Zoysiagrass as Affected by Deficit Irrigation
}

\author{
Jinmin $\mathbf{F u}^{1}$ \\ Department of Plant Science and Landscape Architecture, University of \\ Maryland, College Park, MD 20742
}

Jack Fry ${ }^{2,4}$

Department of Horticulture, Forestry and Recreation Resources, Kansas

State University, 2021 Throckmorton, Manhattan, KS 66506

\begin{abstract}
Bingru Huang ${ }^{3}$
Department of Plant Biology and Pathology, Rutgers University, New Brunswick, NJ 08901
\end{abstract}

Additional index words. carbohydrates, drought, Festuca arundinacea, water, Zoysia japonica

\begin{abstract}
Understanding turfgrass physiological responses to deficit irrigation will help explain potential effects of this practice on turf quality and subsequent stresses. The objective of this study was to investigate the influence of deficit irrigation growth and physiology of 'Falcon II' tall fescue (Festuca arundinacea Schreb) and 'Meyer' zoysiagrass (Zoysia japonica Steud). Turf was subjected to deficit irrigation levels of $20 \%, 40 \%, 60 \%$, $80 \%$, and $100 \%$ of actual evapotranspiration (ET) from June to Sept. 2001 and 2002 in Manhattan, Kans. In an earlier study, minimum deficit irrigation levels required to maintain acceptable quality (MDIL) were determined. We compared growth and physiological parameters at these MDIL with turf irrigated at $100 \%$ ET. Tall fescue had a lower canopy vertical growth rate $(30 \%$ lower $)$, canopy net photosynthesis $\left(P_{n}\right.$, $14 \%$ lower), and whole-plant respiration $\left(R_{w}, 11 \%\right.$ lower $)$ in 1 of 2 years when irrigated at the MDIL compared with $100 \%$ ET; tiller number was not reduced at the MDIL. Water use efficiency $\left(\mu \mathrm{mol} \mathrm{CO}_{2}\right.$ per mmol $\left.\mathrm{H}_{2} \mathrm{O}\right)$ in tall fescue increased by $15 \%$ at the MDIL relative to turf receiving $100 \%$ ET in 1 of 2 years. In zoysiagrass, the MDIL had no effect on any of the growth or physiological parameters measured. Reductions in canopy vertical growth rate at the MDIL in tall fescue during deficit irrigation would likely reduce mowing requirements. Across all deficit irrigation levels, $P_{n}$ was more sensitive to deficit irrigation in both grasses than was $R_{w}$, which could potentially contribute to declines in canopy vertical growth rate, tiller number, and turf quality. Zoysiagrass exhibited higher water use efficiency than tall fescue, particularly at irrigation levels $60 \%$ or more ET.
\end{abstract}

Water availability is becoming limited across many areas of the United States. In recent years, deficit irrigation, or application of water at levels less than maximum evapotranspiration (ET) demand, has been practiced as a strategy to minimize water, resulting in overall water savings. An irrigation deficit can be achieved by returning less water than would occur through actual ET. In some cases, this involves extending the time between irrigations and, in other cases, applying water amounts less than actual ET

Received for publication 15 Aug. 2006. Accepted for publication 17 Oct. 2006 .

Publication no. 07-47-J of the Kansas Agricultural Experiment Station.

We thank Turfgrass Producers International and the Kansas Turfgrass Foundation for supporting this project.

${ }^{1}$ Postdoctoral research associate.

${ }^{2}$ Professor.

${ }^{3}$ Professor.

${ }^{4}$ To whom reprint requests should be addressed; e-mail jfry@oznet.ksu.edu. ability (Beard, 1973). Turfgrass subjected to deficit irrigation or limiting soil moisture may use less water when compared with well-watered turfgrass (Qian and Engelke, 1999). Overall, the extent of allowable deficit irrigation may vary among species and cultivars with warm-season grasses typically being better able to withstand greater levels of deficit irrigation when compared with cool-season grasses (Carrow, 1995; Qian and Engelke, 1999).

In an earlier publication that presented turf quality responses to deficit irrigation in the same study area described here, we reported that tall fescue quality in Kansas was acceptable between June and September when irrigated at $60 \%$ and $80 \%$ of actual ET in 2001 and 2002 (Fu et al., 2004). However, if the turfgrass manager could tolerate 1 week of unacceptable quality, then a MDIL of $40 \%$ and $60 \%$ in 2001 and 2002, respectively, would have sufficed. Zoysiagrass quality was acceptable only when irrigated at $80 \%$ ET. Using the lower MDIL assumptions for tall fescue and $80 \%$ ET irrigation for zoysiagrass, tall fescue required $28 \%$ less water than zoysiagrass in 2001 and the same amount of water as zoysiagrass in 2002.

Our objective was to determine growth and physiological impacts of the previously reported MDIL on tall fescue and zoysiagrass, and also evaluate responses across all deficit irrigation levels.

\section{Materials and Methods}

Plant material and growing conditions. The experiment was conducted using an automated, mobile rainout shelter at the Rocky Ford Turfgrass Research Center at Manhattan, Kans., from 4 June to 14 Sept. 2001 and from 3 June to 13 Sept. 2002. The shelter, $12 \mathrm{~m}$ wide and $15 \mathrm{~m}$ long, was essentially a small building constructed of wood with an A-frame roof and metal siding. During dry weather, the shelter rested just to the north of the study area. The shelter was triggered by a minimum of $0.38 \mathrm{~mm}$ precipitation and required $\approx 2 \mathrm{~min}$ to move south on rails and completely cover the test area. One $\mathrm{h}$ after precipitation stopped, the shelter returned to its resting position. Turf was mowed twice weekly at $5.0 \mathrm{~cm}$ using a rotary mower. Nitrogen from urea $(46-0-0)$ was applied at $49 \mathrm{~kg} \cdot \mathrm{ha}^{-1}$ to tall fescue on 3 May, 19 Sept., and 8 Nov. in 2001 and 3 May, 18 Sept., and 15 Nov. in 2002. Zoysiagrass received an equivalent level of nitrogen on 3 May and 29 June 2001 and 3 May and 5 Aug. 2002. A weather station located $\approx 500 \mathrm{~m}$ from the rainout shelter monitored temperature. Mean maximum air temperatures during each month of the study (2001 and 2002, respectively) were June, 27.8 and $31.1{ }^{\circ} \mathrm{C}$; July, 34.4 and $35^{\circ} \mathrm{C}$; August, 32.8 and $32.8^{\circ} \mathrm{C}$; and September, 28.9 and $32.8^{\circ} \mathrm{C}$. Mean minimum air temperatures for each month of the study (2001 and 2002, respectively) were June, 16.1 and $17.8^{\circ} \mathrm{C}$; July, 21.1 and $20{ }^{\circ} \mathrm{C}$; August, 18.3 and $18.6{ }^{\circ} \mathrm{C}$; and September, 14.4 and $17.2^{\circ} \mathrm{C}$. 
The study was set up as a randomized split-plot design with turfgrass species as the main plots and irrigation levels as the subplots. The main plots measured $5.9 \times 1.8 \mathrm{~m}$ and consisted of 'Meyer' zoysiagrass and 'Falcon II' tall fescue. All main plots were established by sodding on a river-deposited silt loam soil (fine, montomorillonitic, mesic Aquic Arquidolls with a pH 6.4 and phosphorus and potassium of 41 and $367 \mathrm{mg} \cdot \mathrm{kg}^{-1}$, respectively) in Spring 2000 into plot areas that were replicated three times. The subplots measured $1.2 \times 1.8 \mathrm{~m}$ and consisted of irrigation levels of $20 \%, 40 \%, 60 \%, 80 \%$, and $100 \%$ of ET. Each plot was bordered by metal edging (set $15 \mathrm{~cm}$ deep) to minimize lateral movement of water on application.

Plots were irrigated twice weekly using a metered, handheld hose with a shower nozzle and the appropriate amount of water was monitored using a flow meter. Deficit irrigation amounts were determined by taking the fraction of water use $\left(\mathrm{ET}_{100}\right)$ of lysimeter-grown turf receiving $100 \%$ actual ET. Evapotranspiration was measured using lysimeters and the water balance method (Qian et al., 1996b). Lysimeters, one in each plot, were constructed of polyvinylchloride pipe (10.1-cm diameter by $25-\mathrm{cm}$ deep) that had a nylon screen on the bottom end attached with duct tape. An intact soil core with accompanying turf was collected from plots using a $10-\mathrm{cm}$ diameter cup cutter and each was placed in a lysimeter. Lysimeters were then set into holes located in the center of each plot. The day before the study began each year, lysimeters were irrigated until water drained through the bottom of each. Twenty-four hours later, each was sealed on the bottom end with two-layer plastic, weighed to determine its reference weight, and then returned to respective holes in the plot area. To determine ET, lysimeters were removed from the field and weighed between $0100 \mathrm{HR}$ and $0200 \mathrm{HR}$ on Monday and Friday of each week. The mass of water lost from each was recorded and converted to ET. Water was then added to lysimeters using a graduated cylinder to return each to its reference weight before returning to the field.

Deficit irrigation amount for field plots was calculated as: deficit irrigation level $x$ $\mathrm{ET}_{100} \times$ an area adjustment factor. Total water applied to turf receiving $100 \% \mathrm{ET}$ during the study periods in 2001 and 2002, respectively, was as follows: tall fescue, 562 and $598 \mathrm{~mm}$ and zoysiagrass, 390 and $449 \mathrm{~mm}$.

Measurements. Soil water content was measured using a time domain reflectometer (Soil Moisture Equipment Corp., Santa Barbara, Calif.). Two steel probes, 0.63-cm diameter by $25-\mathrm{cm}$ long, were set into at an arbitrary location in each plot in April 2001 and remained in place until removal at the end of the study period in Sept. 2002. Approximately $1 \mathrm{~cm}$ of each probe remained exposed at the soil surface to allow for periodic measurements of soil water content. A 1-cm wide block of wood, with appropriate holes drilled to accommodate probes, was used to protect the probes in the period between measurements. Soil water content at the beginning of the experiment in 2001 averaged $35.7 \%(\mathrm{v} / \mathrm{v})$ across all plots. At the end of the study, soil water content at each irrigation level for tall fescue and zoysiagrass, respectively, were: $20 \%$ ET $(21.8 \%$, $12.3 \%) ; 40 \%$ ET $(24.0 \%, 15.9 \%) ; 60 \%$ ET $(28.4 \%, 20.3 \%) ; 80 \%$ ET $(30.7 \%, 26.5 \%)$; and $100 \%$ ET $(29.4 \%, 25.6 \%)$. In 2002, beginning soil water content across all treatments was $29.7 \%$. At the end of the study in 2002, soil water contents at each irrigation level for tall fescue and zoysiagrass, respectively, were: $20 \%$ ET $(15.1 \%, 8.5 \%) ; 40 \%$ ET $(20.4 \%, 12.0 \%), 60 \%$ ET $(25.1 \%$, $19.3 \%) ; 80 \%$ ET $(27.7 \%, 22.5 \%)$; and $100 \%$ ET $(27.1 \%, 27.0 \%)$.

Turf quality was visually assessed weekly on a 0 to 9 scale in which $0=$ brown or dead turf; $\geq 6.0=$ acceptable quality; and $9=$ optimum greenness and cover.

Canopy vertical growth rate and tiller density were determined every 4 weeks. Canopy vertical growth rate was the difference in turf canopy height before and after cutting on 3-d intervals. A sheet of paper was rested on the canopy surface to measure canopy height as the distance from the paper to the soil surface at eight locations in each subplot. Tiller density was determined by counting numbers of tillers in a $5.1-\mathrm{cm}$ diameter template at two locations in each subplot.

Canopy net photosynthesis $\left(\mathrm{P}_{\mathrm{n}}\right)$ and whole-plant respiration $\left(\mathrm{R}_{\mathrm{w}}\right)$ were measured every 4 weeks beginning on 4 June 2001 and 3 June 2002 using a LI-6400 portable gas exchange system (LI-COR Inc., Lincoln, Neb.). Measurements were made between 0900 and 1500 h. Canopy net photosynthesis was measured by enclosing the turf canopy in a transparent Plexiglas chamber $(15 \times 10 \times 10$ $\mathrm{cm}$ ) attached to the $\mathrm{CO}_{2}$ analyzer on a sunny day. The chamber was pressed into the ground $\approx 3 \mathrm{~cm}$ to provide an adequate seal for canopy gas exchange measurement. Whole plant respiration was determined in the dark by covering the Plexiglas chamber. Data for $\mathrm{P}_{\mathrm{n}}$ and $\mathrm{R}_{\mathrm{w}}$ were expressed as $\mathrm{CO}_{2}$ uptake and evolution per unit turf area.

Water use efficiency $\left(\mu \mathrm{mol} \mathrm{CO}_{2}\right.$ per mmol $\mathrm{H}_{2} \mathrm{O}$ ) was calculated as the photosynthetic rate $\left(\mu \mathrm{mol} \cdot \mathrm{m}^{-2} \cdot \mathrm{s}^{-1} \mathrm{CO}_{2}\right)$ over ET rate $\left(\mathrm{mmol} \cdot \mathrm{m}^{-2} \cdot \mathrm{s}^{-1} \mathrm{H}_{2} \mathrm{O}\right)$.

Data analysis and presentation. Treatment effects were determined by analysis of variance according to the mixed model of Statistical Analysis System (SAS Institute, Cary, N.C.). To remove the effect of year and sampling date, data were analyzed separately for each year and variation was partitioned into grass species, deficit irrigation level, and corresponding interactions. Results indicated a significant species $\times$ deficit irrigation level interaction; therefore, results and discussion focus on responses to deficit irrigation within each turfgrass species. Where multiple measurements were made on an individual plot (e.g., for canopy vertical growth rate and tiller density), measurements were averaged before analysis. Treatment means were separated by a Fisher protected least significant difference test $(P \leq 0.05)$. To clarify presentation and discussion, only comparisons between the MDIL and $100 \%$ ET are presented in tables; where additional discussion across all deficit irrigation levels is included, those values are presented in the text.

\section{Results and Discussion}

At MDIL, growth and physiology of only tall fescue was affected. Zoysiagrass growth and physiology was affected at deficit irrigation levels lower than the MDIL.

Canopy vertical growth rate was reduced at the MDIL in tall fescue in both years (Table 1). Irrigation at levels lower than the MDIL resulted in lower canopy vertical growth rate in both grasses in each year relative to grasses receiving the MDIL (Tables 1 and 2). For example, in 2002, canopy vertical growth rate of tall fescue receiving $20 \%$ ET $\left(1.2 \mathrm{~mm} \cdot \mathrm{d}^{-1}\right)$ was $40 \%$ lower than that irrigated at $100 \%$ ET $\left(2.0 \mathrm{~mm} \cdot \mathrm{d}^{-1}\right)$. In zoysiagrass in 2002, turf irrigated at $20 \%$ ET had a canopy vertical growth rate three times lower than that receiving 100\% ET (1.0 versus $3.0 \mathrm{~mm} \cdot \mathrm{d}^{-1}$, respectively). Maintenance of turf quality with a concomitant reduction in canopy vertical growth rate would be beneficial for the turf manager, because mowing would also likely be reduced.

The reduction in canopy vertical growth rate with increasing irrigation deficits may reflect in the influence of a water deficit on cell expansion. Biran et al. (1981) reported that delaying irrigation until the onset of temporary wilting caused a significant decrease in clipping production in most of the 11 warm and cool-season turfgrasses evaluated. In a greenhouse study with tall fescue conducted by Huang and Fu (2001), withholding irrigation from the upper $20 \mathrm{~cm}$ of a $40-\mathrm{cm}$ soil profile reduced canopy vertical growth rate by $79 \%$ after $16 \mathrm{~d}$ of treatment. A similar reduction in shoot extension rate was observed when Kentucky bluegrass was subjected to drying in the surface $20 \mathrm{~cm}$ of soil (DaCosta et al., 2004). Tiller density was not reduced at the MDIL in tall fescue or zoysiagrass in either year (Tables 1 and 2). Lowest tiller numbers were counted in tall fescue and zoysiagrass subjected to deficit irrigation levels of $20 \%$ and $40 \%$, with reductions in tall fescue of up to $16 \%$ and in zoysiagrass up to $25 \%$ (data not shown).

Canopy net photosynthesis was lower at the MDIL relative to turf receiving $100 \% \mathrm{ET}$ in tall fescue in 2002 (Table 1). The $\mathrm{P}_{\mathrm{n}}$ in tall fescue was consistently lower $(P \leq 0.05)$ at $\geq 60 \%$ ET deficit irrigation levels than in zoysiagrass in both years. For example, in 2002, $\mathrm{P}_{\mathrm{n}}$ in tall fescue at $40 \%$ and $80 \%$ ET were 8.2 and 10.5 $\mu \mathrm{mol} \cdot \mathrm{m}^{-2} \cdot \mathrm{s}^{-1} \mathrm{CO}_{2}$, respectively; zoysiagrass $\mathrm{P}_{\mathrm{n}}$ at $40 \%$ ET was $10.4 \mu \mathrm{mol} \cdot \mathrm{m}^{-2} \cdot \mathrm{s}^{-1} \mathrm{CO}_{2}$ and at $80 \% \mathrm{ET}, 17.2 \mu \mathrm{mol} \cdot \mathrm{m}^{-2} \cdot \mathrm{s}^{-1} \mathrm{CO}_{2}$. These results indicate that zoysiagrass is able to fix more carbon under moderate water deficits when compared with tall fescue. 
Table 1. Growth and physiological responses of tall fescue at the minimum level of deficit irrigation needed to maintain quality (MDIL) and at 100\% evapotranspiration (ET) in 2001 and 2002 at Manhattan, Kans.

\begin{tabular}{|c|c|c|c|}
\hline & Value at MDIL & Value at $100 \%$ ET & $\begin{array}{l}\text { Significance } \\
(P \leq 0.05)^{\mathrm{x}}\end{array}$ \\
\hline \multicolumn{4}{|c|}{2001} \\
\hline \multicolumn{4}{|l|}{$\mathrm{MDIL}=40 \% \mathrm{ET}^{\mathrm{z}}$} \\
\hline \multicolumn{4}{|l|}{ Parameter measured ${ }^{\mathrm{y}}$} \\
\hline Canopy vertical growth rate $\left(\mathrm{mm} \cdot \mathrm{d}^{-1}\right)$ & 1.8 & 2.1 & No \\
\hline Tillers (no./m²) & 16,890 & 17,537 & No \\
\hline $\mathrm{P}_{\mathrm{n}}\left(\mu \mathrm{mol} \cdot \mathrm{m}^{-2} \cdot \mathrm{s}^{-1} \mathrm{CO}_{2}\right)$ & 6.2 & 6.8 & No \\
\hline $\mathrm{R}_{\mathrm{w}}\left(\mu \mathrm{mol} \cdot \mathrm{m}^{-2} \cdot \mathrm{s}^{-1} \mathrm{CO}_{2}\right)$ & 10.5 & 11.8 & Yes \\
\hline WUE $\left(\mu \mathrm{mol} \mathrm{CO} \mathrm{CO}_{2}\right.$ per $\left.\mathrm{mmol}^{-1} \mathrm{H}_{2} \mathrm{O}\right)$ & 1.32 & 1.15 & Yes \\
\hline \multicolumn{4}{|l|}{ 然 } \\
\hline \multicolumn{4}{|l|}{$\mathrm{MDIL}=60 \% \mathrm{ET}$} \\
\hline \multicolumn{4}{|l|}{ Parameter measured } \\
\hline Canopy vertical growth rate $\left(\mathrm{mm} \cdot \mathrm{d}^{-1}\right)$ & 1.4 & 2.0 & Yes \\
\hline Tillers (no./m²) & 16,294 & 16,992 & No \\
\hline $\mathrm{P}_{\mathrm{n}}\left(\mu \mathrm{mol} \cdot \mathrm{m}^{-2} \cdot \mathrm{s}^{-1} \mathrm{CO}_{2}\right)$ & 9.6 & 11.2 & Yes \\
\hline $\mathrm{R}_{\mathrm{w}}\left(\mu \mathrm{mol} \cdot \mathrm{m}^{-2} \mathrm{~s}^{-1} \mathrm{CO}_{2}\right)$ & 8.7 & 9.0 & No \\
\hline Water use efficiency $\left(\mu \mathrm{mol} \mathrm{CO}_{2}\right.$ per $\left.\mathrm{mmol} \mathrm{H}_{2} \mathrm{O}\right)$ & 1.74 & 1.84 & No \\
\hline
\end{tabular}

${ }^{\mathrm{z}}$ Minimum deficit irrigation level required to maintain acceptable turf quality taken from Fu et al. (2004). Irrigation was applied Mondays and Fridays from 4 June to 14 Sept. 2001 and 3 June to 13 Sept. 2002. Total irrigation applied to the 100\% ET treatment was $562 \mathrm{~mm}$ in 2001 and $598 \mathrm{~mm}$ in 2002. The MDIL was $225 \mathrm{~mm}$ in 2001 and $359 \mathrm{~mm}$ in 2002.

${ }^{\mathrm{y}}$ Canopy vertical growth rate, tillers, canopy net photosynthesis $\left(\mathrm{P}_{\mathrm{n}}\right)$, whole plant respiration $\left(\mathrm{R}_{\mathrm{w}}\right)$, and water use efficiency are averages of five measurement dates and four replicates in each year.

${ }^{x}$ Difference between respective parameters measured at the minimum irrigation level and 100\% ET determined using Fisher mean separation test $(P \leq 0.05)$.

The decline in $\mathrm{P}_{\mathrm{n}}$ at the MDIL in tall fescue and likely occurred because $g_{\mathrm{S}}$ is usually reduced in the early stages of a water deficit, which would consequently reduce $P_{n}$. DaCosta and Huang (2005) reported that $\mathrm{P}_{\mathrm{n}}$ of colonial bentgrass (Agrostis tenuis Sibth.) and velvet bentgrass (Agrostis canina L.) irrigated at $60 \%$ and $40 \%$ ET was lower than turf irrigated at $100 \%$ ET. Huang and $\mathrm{Fu}$ (2000) also observed a decline in tall fescue $\mathrm{P}_{\mathrm{n}}$ beginning $9 \mathrm{~d}$ after stopping irrigation in a $40-\mathrm{cm}$ deep root zone in the greenhouse. Decline in $\mathrm{P}_{\mathrm{n}}$ in turfgrass during deficit irrigation may be the result of a loss of leaf area attributable to lower canopy vertical

growth rates and, in some cases, a reduction in turf density.

Whole plant respiration was lower at the MDIL compared with irrigation at $100 \%$ ET in tall fescue in 2001 (Table 1). Canopy photosynthesis of tall fescue and zoysiagrass was inhibited more than respiration across all deficit irrigation levels. For example, in 2002, tall fescue irrigation at $20 \%$ ET caused a $45 \%$ reduction in $\mathrm{P}_{\mathrm{n}}\left(6.2 \mu \mathrm{mol} \cdot \mathrm{m}^{-2} \cdot \mathrm{s}^{-1} \mathrm{CO}_{2}\right)$ compared with turf irrigated at $100 \%$ ET $\left(11.2 \mu \mathrm{mol} \cdot \mathrm{m}^{-2} \cdot \mathrm{s}^{-1} \mathrm{CO}_{2}\right)$. At the same time, however, tall fescue receiving $20 \%$ ET exhibited only a $21 \%$ decline in $\mathrm{R}_{\mathrm{w}}$ $\left(7.1 \mu \mathrm{mol} \cdot \mathrm{m}^{-2} \cdot \mathrm{s}^{-1} \mathrm{CO}_{2}\right)$ compared with turf

Table 2. Growth and physiological responses of Meyer zoysiagrass at the minimum level of deficit irrigation needed to maintain quality (MDIL) and at 100\% evapotranspiration (ET) in 2001 and 2002 at Manhattan, Kans.

\begin{tabular}{|c|c|c|c|}
\hline & Value at MDIL & Value at $100 \%$ ET & $\begin{array}{l}\text { Significance } \\
(P \leq 0.05)^{\mathrm{x}}\end{array}$ \\
\hline \multicolumn{4}{|c|}{2001} \\
\hline \multicolumn{4}{|l|}{ MDIL $=80 \%{ }^{z}$} \\
\hline \multicolumn{4}{|l|}{ Parameter measured } \\
\hline Canopy vertical growth rate $\left(\mathrm{mm} \cdot \mathrm{d}^{-1}\right)^{\mathrm{y}}$ & 2.9 & 2.8 & No \\
\hline Tillers $\left(\right.$ no. $\left./ \mathrm{m}^{2}\right)$ & 29,652 & 29,832 & No \\
\hline $\mathrm{P}_{\mathrm{n}}\left(\mu \mathrm{mol} \cdot \mathrm{m}^{-2} \cdot \mathrm{s}^{-1} \mathrm{CO}_{2}\right)$ & 18.2 & 19.1 & No \\
\hline $\mathrm{R}_{\mathrm{W}}\left(\mu \mathrm{mol} \cdot \mathrm{m}^{-2} \cdot \mathrm{s}^{-1} \mathrm{CO}_{2}\right)$ & 9.7 & 9.9 & No \\
\hline Water use efficiency $\left(\mu \mathrm{mol} \mathrm{CO}_{2}\right.$ per $\left.\mathrm{mmol} \mathrm{H}_{2} \mathrm{O}\right)$ & 2.54 & 2.75 & No \\
\hline \multicolumn{4}{|l|}{2002} \\
\hline \multicolumn{4}{|l|}{ MDIL $=80 \%$} \\
\hline \multicolumn{4}{|l|}{ Parameter measured } \\
\hline Canopy vertical growth rate $\left(\mathrm{mm} \cdot \mathrm{d}^{-1}\right)$ & 3.1 & 3.0 & No \\
\hline Tillers (no./m²) & 33,277 & 32,018 & No \\
\hline $\mathrm{P}_{\mathrm{n}}\left(\mu \mathrm{mol} \cdot \mathrm{s}^{-1} \cdot \mathrm{m}^{-2} \mathrm{CO}_{2}\right)$ & 17.2 & 18.5 & No \\
\hline $\mathrm{R}_{\mathrm{W}}\left(\mu \mathrm{mol} \cdot \mathrm{s}^{-1} \cdot \mathrm{m}^{-2} \mathrm{CO}_{2}\right)$ & 8.4 & 8.7 & No \\
\hline Water use efficiency $\left(\mu \mathrm{mol} \mathrm{CO} \mathrm{CO}_{2}\right.$ per $\left.\mathrm{mmol} \mathrm{H}_{2} \mathrm{O}\right)$ & 3.79 & 3.82 & No \\
\hline \multicolumn{4}{|c|}{ 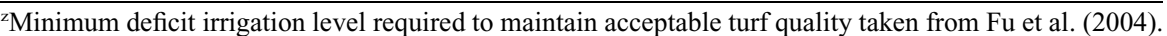 } \\
\hline \multicolumn{4}{|c|}{ Irrigation was applied Mondays and Fridays from 4 June to 14 Sept. 2001 and 3 June to 13 Sept. 2002.} \\
\hline \multirow{2}{*}{\multicolumn{4}{|c|}{$\begin{array}{l}\text { Total irrigation applied to the } 100 \% \text { ET treatment was } 390 \mathrm{~mm} \text { in } 2001 \text { and } 449 \mathrm{~mm} \text { in } 2002 \text {. The MDIL } \\
\text { was } 312 \mathrm{~mm} \text { in } 2001 \text { and } 359 \mathrm{~mm} \text { in } 2002 \text {. }\end{array}$}} \\
\hline & & & \\
\hline \multicolumn{4}{|c|}{$\begin{array}{l}{ }^{\mathrm{y}} \text { Canopy vertical growth rate, tillers, canopy net photosynthesis }\left(\mathrm{P}_{\mathrm{n}}\right) \text {, whole plant respiration }\left(\mathrm{R}_{\mathrm{w}}\right) \text {, and } \\
\text { water use efficiency are averages of five measurement dates and four replicates in each year. } \\
\text { x Difference between respective parameters measured at the minimum irrigation level and } 100 \% \text { ET } \\
\text { determined using Fisher mean separation test }(P \leq 0.05) \text {. }\end{array}$} \\
\hline
\end{tabular}

irrigated at $100 \% \mathrm{ET}\left(9.0 \mu \mathrm{mol} \cdot \mathrm{m}^{-2} \cdot \mathrm{s}^{-1} \mathrm{CO}_{2}\right)$. In zoysiagrass, the decline was even more dramatic, with turf irrigated at $20 \%$ ET exhibiting a $70 \%$ decline in $\mathrm{P}_{\mathrm{n}}\left(5.6 \mu \mathrm{mol} \cdot \mathrm{m}^{-2} \cdot \mathrm{s}^{-1}\right.$ $\mathrm{CO}_{2}$ ) compared with turf irrigated at $100 \%$ ET $\left(18.5 \mu \mathrm{mol} \cdot \mathrm{m}^{-2} \cdot \mathrm{s}^{-1} \mathrm{CO}_{2}\right)$. Respiration in zoysiagrass receiving $20 \%$ ET was $38 \%$ lower than in turf receiving $100 \%$ ET. Others have also reported that respiration was less affected by drought stress than photosynthesis (Saradadevik, 1994). The imbalance between $P_{n}$ and $R_{w}$ could lead to limited carbohydrate availability (Huang and $\mathrm{Fu}$, 2000; Huang and Gao, 2000; Schmidt and Blaser, 1967) and exacerbate the declines in canopy vertical growth rate and tiller density. An extended period with such an imbalance between photosynthesis and respiration could also potentially influence resistance of both zoysiagrass and tall fescue to abiotic and biotic stresses, because carbohydrate reserves may be reduced (Fry and Huang, 2004).

Water use efficiency was unaffected at the MDIL in tall fescue or zoysiagrass (Tables 1 and 2). At $100 \%$ ET irrigation, zoysiagrass had WUE values twice those of tall fescue, which was likely the result of the more efficient $\mathrm{C}_{4}$ photosynthetic pathway used by zoysiagrass compared with the $\mathrm{C}_{3}$ pathway in tall fescue (Fry and Huang, 2004). High WUE occurs when carbon fixation is maintained and the turfgrass uses relatively low amounts of water. Water use efficiency in zoysiagrass declined more rapidly than in tall fescue because irrigation was reduced. In 2002 , for example, the range of WUE in tall fescue was $1.11 \mu \mathrm{mol} \mathrm{CO}_{2}$ per mmol $\mathrm{H}_{2} \mathrm{O}$ (20\% ET irrigation) to $1.15 \mu \mathrm{mol} \mathrm{CO}_{2}$ per $\mathrm{mmol} \mathrm{H}_{2} \mathrm{O}$ (100\% ET irrigation), whereas the range in zoysiagrass was $1.32 \mu \mathrm{mol} \mathrm{CO}_{2}$ per mmol $\mathrm{H}_{2} \mathrm{O}(20 \%$ ET irrigation) to $3.82 \mu \mathrm{mol}$ $\mathrm{CO}_{2}$ per $\mathrm{mmol} \mathrm{H}_{2} \mathrm{O}$ (100\% ET irrigation). This suggests that WUE in tall fescue is less sensitive to deficit irrigation than in zoysiagrass. A decrease in WUE with water availability has been observed in Kentucky bluegrass (Ebdon and Kopp, 2004). These results generally contradict crop (yield) studies in which WUE increases with water deficit (Starman and Lombardini, 2006). In yield studies, however, WUE is generally based on accumulative yield produced relative to the amount of water consumed.

As MDIL was defined by Fu et al. (2004), tall fescue required a total of $88 \mathrm{~mm}$ less water than zoysiagrass between June and September in 2001 and 2002. Nevertheless, zoysiagrass exhibited higher WUE than tall fescue, particularly at irrigation levels $\geq 60 \%$ ET. This reflects the drought resistance capability of tall fescue that is afforded by rooting more deeply than zoysiagrass (Qian et al., 1996a), despite having a higher water use rate than zoysiagrass (Qian et al., 1996b).

Here, relative to turf receiving $100 \%$ ET, tall fescue exhibited reduced canopy vertical growth rate, $\mathrm{P}_{\mathrm{n}}$, and $\mathrm{R}_{\mathrm{w}}$ in 1 of 2 years at the MDIL. Tiller number was unaffected in tall fescue at the MDIL, whereas WUE increased by $15 \%$ in 1 of 2 years. Zoysiagrass growth and carbon metabolism were unaffected at 
the MDIL in either year. Across all deficit irrigation levels, $P_{n}$ was more sensitive to deficit irrigation in both grasses than was $R_{w}$, which could potentially contribute to declines in canopy vertical growth rate, tiller number, and turf quality.

\section{Literature Cited}

Beard, J.B. 1973. Turfgrass: Science and culture. Prentice-Hall, Englewood Cliffs, N.J.

Biran, I., B. Bravdo, I. Bushkin-Harav, and E. Rawitz. 1981. Water consumption and growth rate of 11 turfgrasses as affected by mowing height, irrigation frequency, and soil moisture. Agron. J. 73:85-90.

Brown, C.A., D.A. Devitt, and R.L. Morris. 2004. Water use and physiological response of tall fescue turf to water deficit irrigation in an arid environment. HortScience 39:388-393.

Carrow, R.N. 1995. Drought resistance aspects of turfgrasses in the southeast: ET and crop coefficients. Crop Sci. 35:1685-1690.

DaCosta, M. and B.R. Huang. 2005. Minimum water requirements for creeping, colonial, and velvet bentgrass under fairway conditions. Crop Sci. 46:81-89.

DaCosta, M., Z.L. Wang, and B.R. Huang. 2004. Physiological adaptation of Kentucky blue- grass to localized soil drying. Crop Sci. 44:1307-1314.

Ebdon, J.S. and K.L. Kopp. 2004. Relationship between water use efficiency, carbon isotope discrimination, and turf performance in genotypes of Kentucky bluegrass during drought. Crop Sci. 44:1754-1762.

Feldhake, C.M., R.E. Danielson, and J.D. Butler. 1984. Turfgrass evapotranspiration. II. Responses to deficit irrigation. Agron. J. 76:85-89.

Fry, J.D. and J.D. Butler. 1989. Response of tall and hard fescue to deficit irrigation. Crop Sci. 29:1536-1541.

Fry, J. and B. Huang. 2004. Applied turfgrass science and physiology. John Wiley \& Sons, Inc., Hoboken, N.J.

Fu, J., J. Fry, and B. Huang. 2004. Minimum water requirements of four turfgrasses in the transition zone. HortScience 39:1740-1744.

Huang, B. and J. Fu. 2000. Photosynthesis, respiration, and carbon allocation of two coolseason perennial grasses in response to surface soil drying. Plant Soil 227:17-26.

Huang, B. and J. Fu. 2001. Growth and physiological responses of tall fescue to surface soil drying. Intl. Turfgrass Soc. Res. J. 9:291-296.

Huang, B. and H. Gao. 2000. Growth and carbohydrate metabolism of creeping bentgrass cultivars in response to increasing temperature. Crop Sci. 40:1115-1120.
Pande, H. and J.S. Singh. 1981. Comparative biomass and water status of four range grasses grown under two soil water conditions. J. Range Mgt. 34:280-284.

Qian, Y.L. and M.C. Engelke. 1999. Performance of five turfgrasses under linear gradient irrigation. HortScience 34:893-896.

Qian, Y.L., J.D. Fry, and W.S. Upham. 1996a. Rooting and drought avoidance of warmseason grasses and tall fescue in Kansas. Crop Sci. 31:1331-1334.

Qian, Y.L., J.D. Fry, S.C. Wiest, and W.S. Upham. 1996b. Estimating turfgrass evapotranspiration using atmometers and the Penman-Monteith model. Crop Sci. 36:699-704.

Saradadevik, R.A. 1994. Inhibition of photosynthesis by osmotic-stress in pea (Pisum-sativum) mesophyll protoplasts in intensified by chilling or photoinhibitory light-intriguing responses of respiration. Plant Cell Environ. 17:739-746.

Schmidt, R.E. and R.E. Blaser. 1967. Effect of temperature, light, and nitrogen on growth and metabolism of 'Cohansey' bentgrass (Agrostis palustris). Crop Sci. 7:447-451.

Starman, T. and L. Lombardini. 2006. Growth, gas exchange, and chlorophyll fluorescence of four ornamental herbaceous perennials during water deficit conditions. J. Amer. Soc. Hort. Sci. 131:469-475. 